\title{
雷雲中の降水粒子分布測定に基づく 電荷量と電場の推定手法に関する研究 \\ A STUDY ON ESTIMATION OF CHARGE AND ELECTRIC FIELD BASED ON THE PRECIPITATION PARTICLE DISTRIBUTION MEASUREMENT IN THUNDERCLOUD
}

\author{
小池雄大 1 ・大石哲 2 ・小川まり子3 \\ Yudai KOIKE, Satoru OISHI and Mariko OGAWA \\ 1学生会員 神戸大学大学院工学研究科（干657-8501 兵庫県神戸市灘区六甲台町1-1） \\ 2フェロー会員 工博 神戸大学教授 都市安全研究センター（† 657-8501 兵庫県神戸市灘区六甲台町1-1） \\ 3学生会員 工修 神戸大学大学院工学研究科（†657-8501 兵庫県神戸市灘区六甲台町1-1）
}

\begin{abstract}
The present study describes estimation of charge and electric field based on the precipitation particle distribution measurement in thundercloud. An X band multi parameter (MP-X) radar and a multi LF sensor network (BOLT) as lightning detectors were used. Polarization parameters obtained from MP-X radar were used to perform the precipitation particle distinction. Distinguished particle distribution from the polarization parameters including graupel gives particle size distribution, and electric charge amount in the collision of graupel and ice crystals. By solving the Poisson equation with charge amount obtained, the electric potential and the electric field have been calculated.

In fact, the present study shows possibility to predict lightning by using MP-X radar through calculating charge and electric field in real time.
\end{abstract}

Key Words : multi parameter radar, particle distinction, particle size distribution, charge and electric field, graupel and ice crystals

\section{1. 本研究の背景と目的}

近年，問題となっているゲリラ豪雨が今回の研究の背 景にある. 一般的に，雷はゲリラ豪雨に先行して発生す ることが多いため，雷とゲリラ豪雨の関係により予測を 行うことを考えた。しかし，現時点では雷と豪雨の相関 関係で未解明な点が多く, すぐにゲリラ豪雨の予測をす ることは困難と考えられる. そこで，本研究では気象 レーダーを使用して, 雷発生のメカニズムの検証を行う. 雷放電に関して先行研究からわかっていることを述心゙ る. 河崎 $^{1}{ }^{2}$ とよと，雷放電をより厳密に定義するなら， 雷雲内に蓄えられている電荷群が，大気の絶縁を破壊し て導電性の高い道（放電路）を形成し，その結果正負電 荷を短絡して起こる中和現象として表現することが妥当 である。そしてその中和が雷雲・大地間で起こる場合を 対地放電（または落雷），一つの雷雲内で起こる場合を 雲内放電，異なる雷雲間で起こる場合を雲間放電と呼ん でおり，これら雲内放電および雲間放電は一まとめにし
て雲放電と呼んでいる．電荷の中和は雲の中で始まり， 雲の中でも電荷の中和がしきれない時，大地との間で中 和を行う.

雷における被害は停電, 鉄道障害, 火災, 人身傷害, 電子器具, 通信障害, 航空機障害などに及び, 大きな被 害をもたらす。そのため, 落雷を予測し, 未然に落雷事 故を防ぐことが重要である.

過去の研究としてTakahashi ${ }^{2}$ が軸対称 2 次元雲モデル を用いた雷モデルを開発した。このモデルの電荷分離機 構には着水電荷分離機構, イオン拡散, 誘導イオン拡散 機構, 地上からのコロナ放電機構が含まれており, 雷放 電は主な空間電荷間で発生し，20C（クーロン） 中和 される.さらに3次元雲解像モデルを用いた雷モデルを MacGorman et al. ${ }^{3)}$ が開発した. このモデルの電荷分離機 構には着水電荷分離機構と水滴，水晶，霰同士の衝突 • 分離の際，電場によって誘起された誘導電荷を片方が持 ち去る誘導電荷分離が含まれる.

また，発雷予測手法は，金子4)が雲解像モデル

（CReSS: Cloud Resolving Storm Simulator）を用いて，雷 
雲内電荷分布と雷を再現する雷モデルを開発した．雲の 雷活動を『雲構成粒子の帯電による電荷の蓄積』と『発 雷による電荷の消費』の2つに大きく分け，電荷を予報 変数として新たに導入し, 雲の帯電機構は, 微物理過程 において発生する水晶, 雪, 霰の帯電機構である着水電 荷分離機構を用いている. また電荷分離, 電荷分布のモ デル化を行い，電荷分布から電位，そして電場の計算を 行っている. 発雷判定については，電場を発雷のしきい 值とし, 発雷後の電荷の消費をパラメタライズする発雷 パラメタリゼーションを用いた雷モデルの開発を行って いる.

しかし, これらの研究は, 数值シミュレーションによ る発雷予測であり, 実際に観測されたデータから発雷予 測を行った研究は今なおない.

そこで，本研究では気象レーダーを使用した電場の計 算アルゴリズムの構築を行った. 具体的には，Xバンド レーダーを用いて粒子判別された降水粒子の粒径分布推 定結果から大気中の電荷分布を算出し, 電場の計算を 行った.

\section{2. 観測装置}

\section{（1）Xバンド偏波ドップラーレーダー}

本研究では名古屋大学所有の気象用Xバンド偏波ドッ プラーレーダー（東芝製固体素子タイプ，以下GINと称 する）を用いる．GINは神戸国際大学に設置され，覆域 $64 \mathrm{~km}$, 空間分解能 $150 \mathrm{~m}$, 駆動速度方位角 $3 \mathrm{rpm}$ で通常は Plan Position Indicator (PPI) 走查を行っており，15仰角 を6分間かけてボリュームスキャンを行っている.

\section{(2) 雷探知装置}

雷探知装置は吉田ら ${ }^{5)}$ が開発した多地点LF帯センサ (以下, Broadband Observation network for Lightning and Thunderstorm， BOLTと称する）を用いる．BOLTは雷 放電時に放射されるLF帯電磁波を11地点のLF帯センサ で受信してその放射源位置推定を行うものである．観測 範囲が半径 $200 \mathrm{~km}$ と広範囲の雷進展を捉えることが可能 である。

\section{3. 雷雲中の降水粒子分布測定に基づく電荷量と}

\section{電場の推定手法}

雷電気の主な電荷の担い手は霞，氷晶と考えられる. 金子出によると，雷は雷雲内の落下や上昇による帯電粒 子の運動によって分離されて強まった電気エネルギーを 電気的に中和するために発生する. 雷雲内の電荷分布に よって作られる電場に電子やイオンが作用され加速され
る. その時加速が十分で一定以上の運動エネルギーを持 つと他の分子と衝突・電離して新たな電荷を生成する.

この作用が雪崩式に発生すると正電荷と負電荷の共存す る放電路が作られる。この放電路は一般的に導体の特徴 を示寸といわれ，放電路表面に放電路内の電場をうち消 すように電荷が分布する. この電荷は一般的に放電路先 端に集中寸る. その電荷符号は線上放電路の一方の端で は正，もう一方の端では負となるのが一般的で，その電 荷がその付近の電場を強化する方向に働く．このことに よって放電の開始点と同様に大気の絶縁効果が破壊され 放電路が伸びていく，放電路の開始には実質的に電場の 強度が重要でこの值がしきい值以上に達寸ると放電が開 始される. 雷の効果で最も主要なものは雷雲内の電荷を 中和することである. 正電荷と負電荷が合わさって中性 になることをいう。雷雲内への作用としては, 電荷分布 による電気エネルギーを減らす方向に作用し, それは 正・負電荷それぞれ絶対量を減らすことになる.

本研究では, 雲の帯電機構である着水電荷分離機構を 基に電荷量, 電場の推定を行う。気象レーダーから得ら れる偏波パラメータであるレーダー反射因子，レーダー 反射因子差，伝搬位相差変化率，偏波間相関係数（以下 それぞれZH，ZDR，KDP， $\rho \mathrm{HV}$ と称する）を用いて, 降水粒子判別を行い, 粒子判別の結果, 霞または霰と水 晶の混在状態または霞と氷晶と雪片の混在状態と判定さ れたデータを使用し，偏波パラメータから霞の粒径分布 を算出する．ここで，粒子判別では混在状態を考慮して いるが，霞と水晶の混在状態，霞と水晶と雪片の混在状 態と判定されたデータは主に，霞を観測していると仮定 寸る. 次に, 求めた霰の粒径分布から靇の電荷量を求め, 電荷量からポアソン方程式を解くことで，電位と電場を 算出する.

本研究では気象レーダーを用いた電場の計算アルゴリ ズムの構築が目的であるため，今回は試算として $4 \times 4 \times$ 4の狭い領域でのみの計算を行った. 図-1に電荷量から 電場までの推定手法を示す。

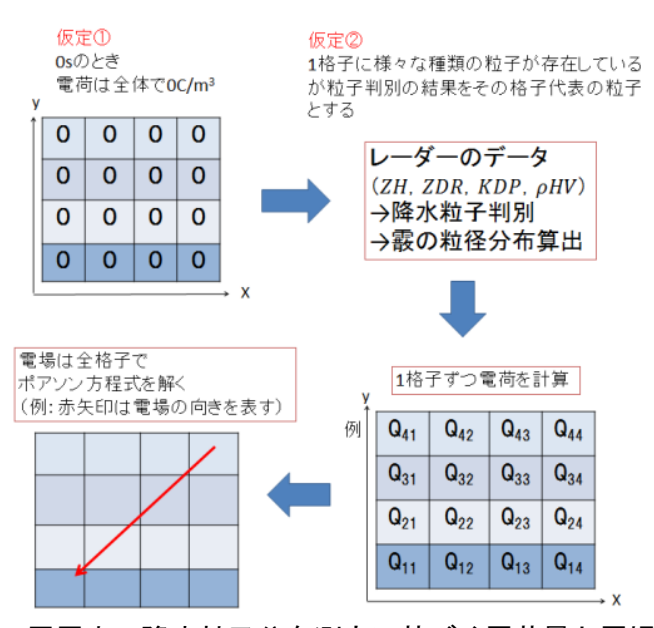

図-1＼cjkstart雷雲中の降水粒子分布測定に基づく電荷量と電場の推 定手法 


\section{(1) 降水粒子判別手法}

本研究では降水粒子判別手法として中北らのの方法を 利用している．MPレーダーの観測情報は降水粒子の大 きさ，形，向き，相変化や落下形態などの特性を偏波パ ラメータによって推定することが可能であるので，降水 粒子の種類を分類するために利用可能である. 中北ら は，Cバンド型偏波ドップラーレーダーCOBRAを用い て降水粒子の種類（雨滴，凍結水，霰，水晶および雪 片）を推定する手法を確立した。同期観測したCバンド 偏波ドップラーレーダーの偏波パラメータ（ZH，ZDR， $\mathrm{KDP}, \rho \mathrm{HV})$ を使って粒子判別を行った. この方法はそ の後Xバンドレーダーに拡大され, 本研究ではXバンド のアルゴリズムを用いて降水粒子判別を行った。

\section{(2) 霰の粒径分布推定手法}

霞の粒径分布 $N(D)$ は以下の式で表せる.

$$
N(D)=N_{0} \exp (-\Lambda D)
$$

ここで，粒径分布関数の $N_{0}\left[\mathrm{~m}^{-1} \mathrm{~m}^{-3}\right], \Lambda\left[\mathrm{m}^{-1}\right]$ はそれぞ れ粒径分布のパラメータ, $D[\mathrm{~m}]$ は霰の粒径を表す。

粒径分布のパラメータ $N_{0}$ とムを求める時に，MPレー ダーで観測される偏波パラメータ (ZH，ZDR，KDP） を利用する，図-2より，ZDRから霞の扁平率を求める. 図-2は霰を扁球と仮定し，ランダムに回転させた場合の 数值計算結果であり，扁長の霰に関しては考慮していな い. 粒子判別では一格子に存在する様々な種類の粒子の 中から代表した粒子を粒子判別で表示しているが，ここ では1つの粒子に着目すると仮定する.

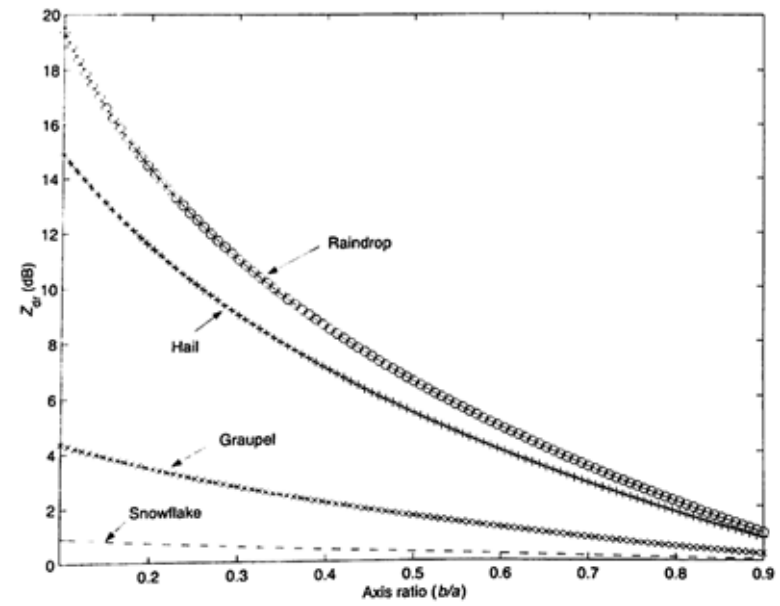

図-2 ZDRと扁平率 $(\mathrm{b} / \mathrm{a})$ の関係 ${ }^{7}$

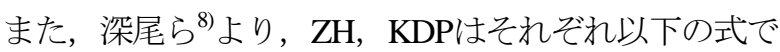
表せる.

$$
\begin{gathered}
Z H=\int_{0}^{\infty} D^{6} N(D) d D=\frac{N_{0} \times 6 !}{\Lambda^{7}} \\
K D P=\frac{\pi k C_{k}}{12} \int D^{3}\left(1-\frac{b}{a}\right) N(D) d D \\
=\frac{\pi k C_{k}\left(1-\frac{b}{a}\right)}{12} \frac{N_{0} \times 3 !}{\Lambda^{4}}
\end{gathered}
$$

ここで，kはレーダー電波の波数 $(=202.68 / \mathrm{m}) ， C_{k}$ は 周波数による定数（=3.75）, b/aは霞の扁平率を表す.

また，霞の空間数濃度 $n(u)$ は下の式で表せる.

$$
n(u)=\int_{0}^{\infty} N(D) d D=\frac{N_{0}}{\Lambda}
$$

(4)式より, 霞の空間数濃度を算出するには，霞の粒径 分布を求めればよい.

\section{（3）霰の電荷量推定手法}

着水電荷分離機構によると霞と水晶が衝突するときに, 霞と氷晶の間で電荷の受け渡しが起こり, 結果, 霞と氷 晶が逆符号・同量の電荷を分け合う。

金子 ${ }^{4}$ はTakahashi ${ }^{2}$ が低温室内で金属円柱を用いて実験 して得られた着水電荷分離機構を取り入れて, 霰と水晶 の衝突における電荷分離は以下の式で表しているので, 本研究でもそれを採用する.

$$
\begin{aligned}
& \frac{\partial Q_{g-i}}{\partial t}=\int_{0}^{\infty} \int_{0}^{\infty} \alpha \frac{\partial q_{\text {charge }}}{\partial t} n_{g 0} \exp \left(-\Lambda_{g} D_{g}\right) d D_{g} d D_{i} \\
& \cong \frac{5 \pi \bar{D}_{i}{ }^{2} N_{i} n_{g 0} q E_{\text {sep }} \alpha_{u g}{ }^{2}}{4 V_{0} D_{0}{ }^{2}}\left(\frac{\rho_{0}}{\rho}\right)^{2 \gamma_{u g}} \Gamma\left(3+2 \beta_{u g}\right) \bar{D}_{g}{ }^{3+2 \beta_{u g}}
\end{aligned}
$$

$\alpha$ は以下の通りである.

$$
\alpha=5\left(\frac{D_{i}}{D_{0}}\right)^{2} \frac{\left|U_{g}\left(D_{g}\right)-U_{i}\left(D_{i}\right)\right|}{V_{0}}
$$

ここで，氷晶の落下速度は霞の落下速度に比べて無視 できるほど小さいと仮定する，Qはモデル格子内の霞の 電荷密度 $\left(\mathrm{C} / \mathrm{m}^{3}\right) ， t$ は時間， $g$ は霞（graupel）， lは水晶 (icecrystal)， $q_{\text {charge }}$ は霞一個の電荷密度 $\left(\mathrm{C} / \mathrm{m}^{3}\right) ， n_{g 0}$ は 霞の数密度の切片 $\left(=N_{0}\right)$, A は粒子直径, $\bar{D}$ は平均粒子直径, $N$ は粒子数濃度, $q$ は 帯電係数（分離電荷量） $\quad\left(=0.015 \mathrm{pC}=1.5 \times 10^{-14} \mathrm{C}\right), E_{\text {sep }}$ は衝突分離係数 $(=1) ， V_{0}$ は基準落下速度 $(=8 \mathrm{~m} / \mathrm{s})$, 


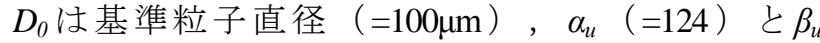
$(=0.64)$ と $\gamma_{u} \quad(=0.5)$ はそれぞれ落下速度の形状パラ メータ， $\bar{D}_{g}$ は霰の粒径分布の中心值を表す。ここで， 基本場の地表面の空気密度 $\rho_{0}$ を水蒸気と水物質を考慮し た湿潤大気密度 $\rho$ で割った值を 1 と仮定する．また，水晶 は雲内に無数に存在しているため, レーダーから正確な 数を測定することは困難である，そのため，本研究では 高橋 ${ }^{9)}$ より, $\bar{D}_{i}$ の水晶の平均粒子直径を $200 \mu \mathrm{m}, N_{i}$ の水 晶の空間数濃度を $5 \times 10^{4} / \mathrm{m}^{3}$ と仮定する. また, $U_{g}\left(D_{g}\right)$, $U_{i}\left(D_{i}\right)$ はそれぞれ霰, 水晶の粒径に忘じた落下速度を表 于.

(5)式より， $n_{g 0}$ と $\bar{D}_{g}$ を求めれば電荷量が算出できるこ とが分かる. (5)式を積分し, 初期条件で $t=0$ のとき, $Q=0$ と仮定することで，単位時間当たりの電荷量は以下 の式で求められる.

$$
Q_{g-i}=\frac{5 \pi \bar{D}_{i}{ }^{2} N_{i} n_{g 0} q \alpha_{u g}{ }^{2}}{4 V_{0} D_{0}{ }^{2}} \Gamma\left(3+2 \beta_{u g}\right) \bar{D}_{g}{ }^{3+2 \beta_{u g}} \times t
$$

\section{（4）霞の電位，電場推定手法}

電位は電荷分布によって決まる。電場ベクトルは電位 の傾きによって決まる. 電位のポアソン方程式, 電場の 式はそれぞれ以下のように表せる.

$$
\begin{gathered}
\nabla^{2} V=-\frac{Q}{\varepsilon_{0}} \\
\vec{E}=-\nabla V
\end{gathered}
$$

$V$ は電位 $[\mathrm{V}], Q$ は電荷密度 $\left[\mathrm{C} / \mathrm{m}^{3}\right], \varepsilon_{0}$ は真空の誘電率 $\left(=8.85 \times 10^{-12} \mathrm{~F} / \mathrm{m}\right) ， \vec{E}$ は電場ベクトル $[\mathrm{V} / \mathrm{m}]$ を表す. 1 格子毎にそれぞれ電荷密度 $Q\left[\mathrm{C} / \mathrm{m}^{3}\right]$ の值があり, $4 \times 4 \times 4$ 格子の周りの電荷は $0 \mathrm{C} / \mathrm{m}^{3}$, 電位は $0 \mathrm{~V}$ とおいた. (8)式の ポアソン方程式を収束するまで繰り返し計算を行い, 電 位を算出する，その後，電位から電場を算出する.

\section{(5)計算結果}

2012年10月28日18時の天気図 ${ }^{10}$ を示す (図-3) 。気象 庁11)によると，この日は18：13に神戸観測所で北方向5 $\mathrm{km}$ 未満の距離で強度2の雷電を確認し, 断続的に $18: 50$ まで確認している。.また，降水量は神戸観測所で18:20 に10分間で $6.5 \mathrm{~mm}$, 降雨強度に換算すると $39.0 \mathrm{~mm} / \mathrm{hr}$ の 強い雨が降り, しばらく雨が降り続いている.

本研究の観測範囲を図-4に示寸.また，電場の計算を 行った範囲を図-4に赤枠で示した.

図-5は2012年10月28日18:20に観測されたGINとBOLT
をAVS可視化ツールを用いて三次元表示した結果である. ここで，図の下面は大阪湾周辺の地形を立体表示し，赤， 緑，青の等值面は雷雲を表している．色はレーダー反射 因子を表している. 黄色の点はBOLTで観測された雷の 分岐点を表している.

図-5より，レーダーエコーが強い部分にリンクして LF波が発生していることが目視で確認できる.

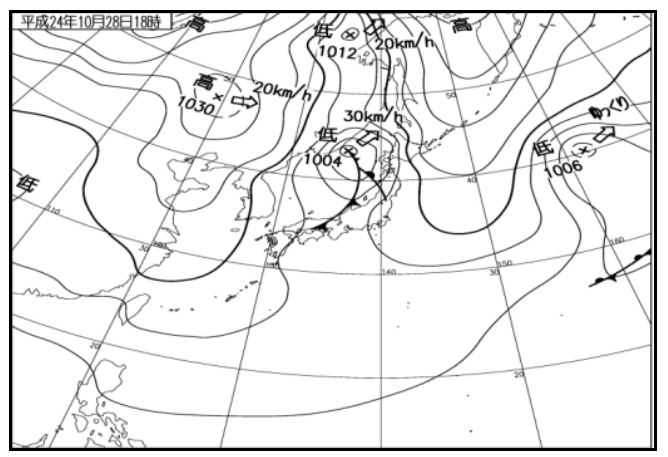

図-3 2012年10月28日18時の天気図 ${ }^{10)}$

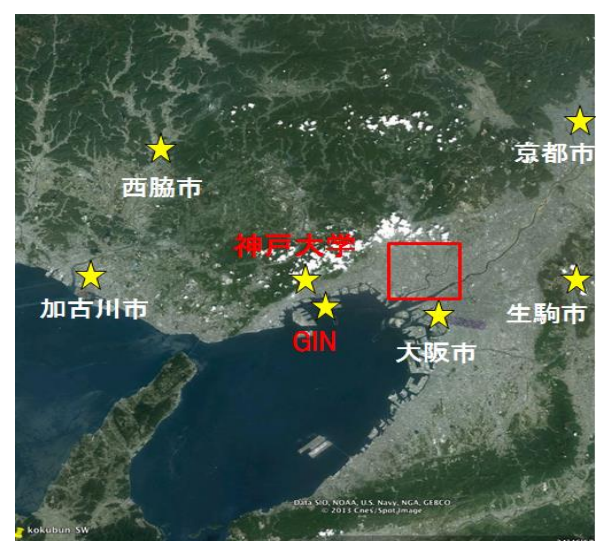

図-4＼cjkstart解析対象範囲（赤枠は電場の計算範囲を表す）

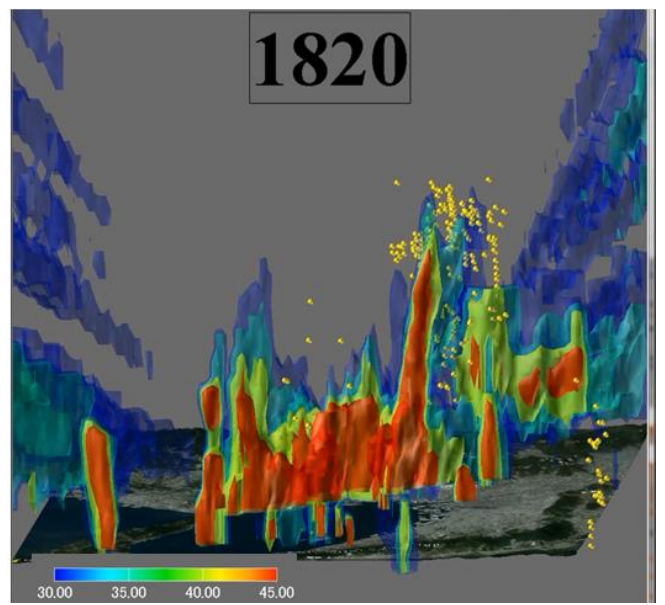

図-5 2012年10月28日18:20のGINとBOLTによる事例解析結果 (鳥瞰図)

カラーバー : レーダーエコーの強さ $[\mathrm{dBz}]$

黄色の点 : 雷放電 


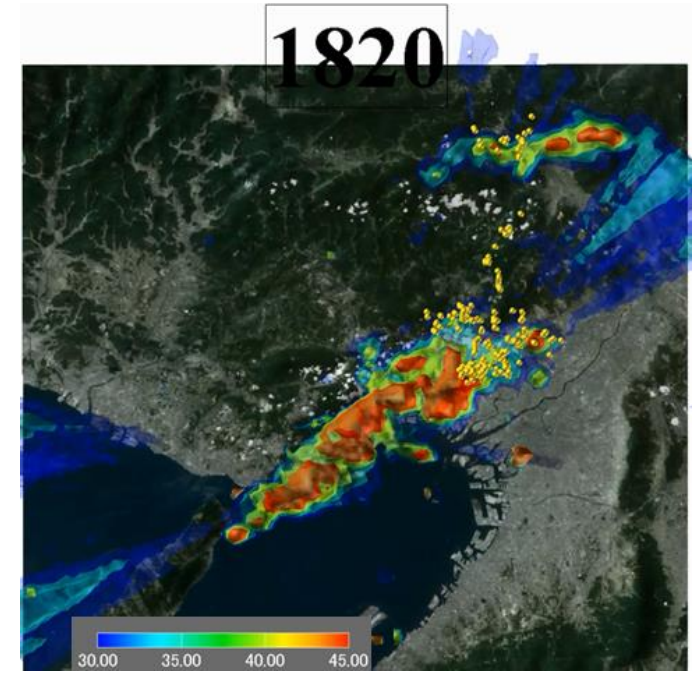

図-5（続き） 2012年10月28日18:20のGINとBOLTによる事例解 析結果 (平面図)

カラーバー : レーダーエコーの強さ $[\mathrm{dBz}]$

黄色の点 : 雷放電

本研究では図-4に示した赤枠の範囲について電荷と電 場を計算した。図-5と同じ日時の2012年10月28日18時20 分の事例を検討する.

GINで得られた偏波パラメータから粒子判別と電荷量 の計算を行った結果を図-6に示した。また，AVSを用い て図-7から図-11にGINによる鉛直断面の霰の数濃度, 電荷分布，電位分布，電場分布を示した。 ここで，Xの 90～93格子はGINから東に19km～22km，Yの142～145格 子はGINから北に $3 \mathrm{~km} \sim 6 \mathrm{~km}, \mathrm{Z}$ の $14 〜 17$ 格子はGINから 上空に $6.75 \mathrm{~km} \sim 8.25 \mathrm{~km}$ の位置を表す.
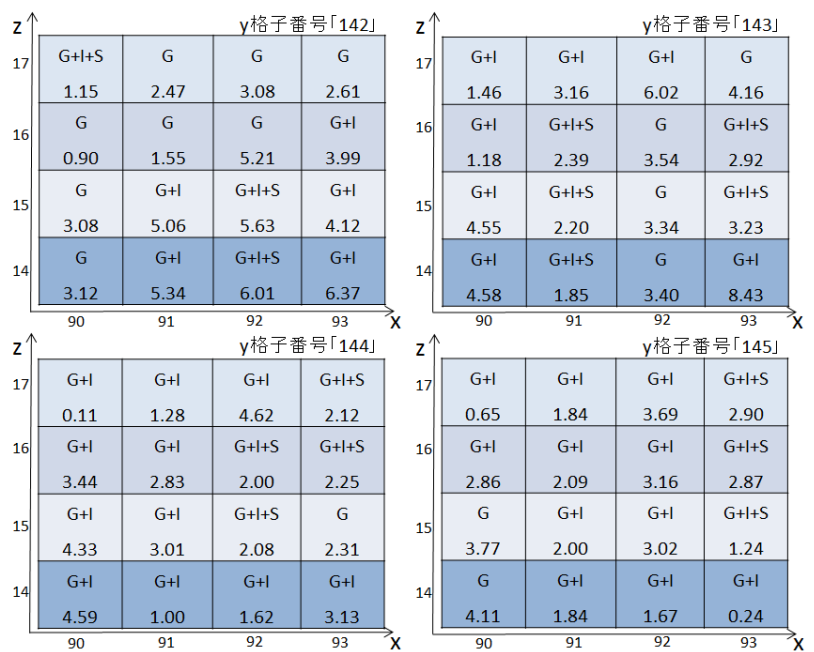

図-6 2012年10月28日18時20分のGINIよる10秒後の粒子判別 と電荷量算出の結果 (単位 : $1 \times 10^{-9}\left[\mathrm{C} / \mathrm{m}^{3}\right]$ )

$(G$ : 霰, $G+I$ : 霰と氷晶の混在状態, $G+I+S$ : 霰と水晶と 雪片の混在状態を表す)

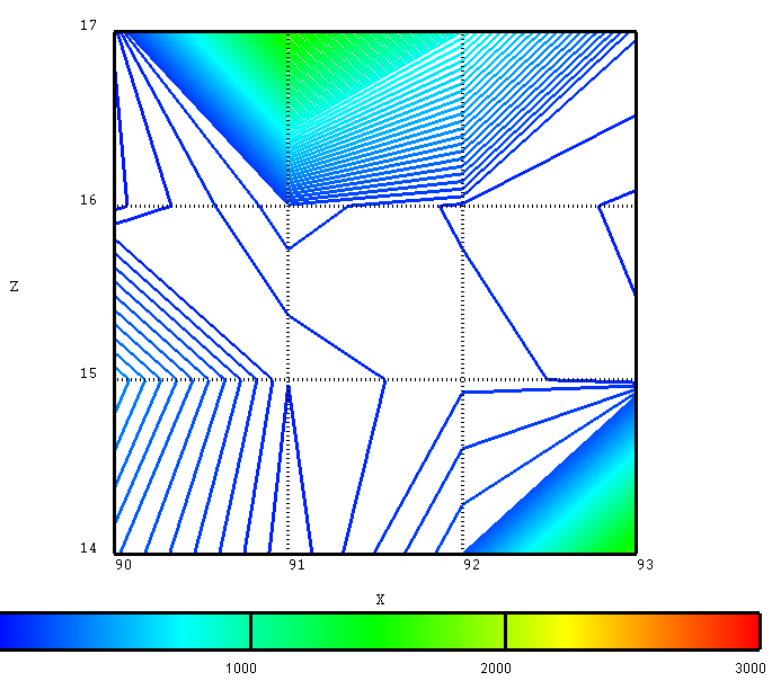

図-7 2012年10月28日18時20分のGINIによる観測結果

霰の数濃度 $\left[\right.$ 個 $\left./ \mathrm{m}^{3}\right]$ の鉛直断面 (Y格子=143)

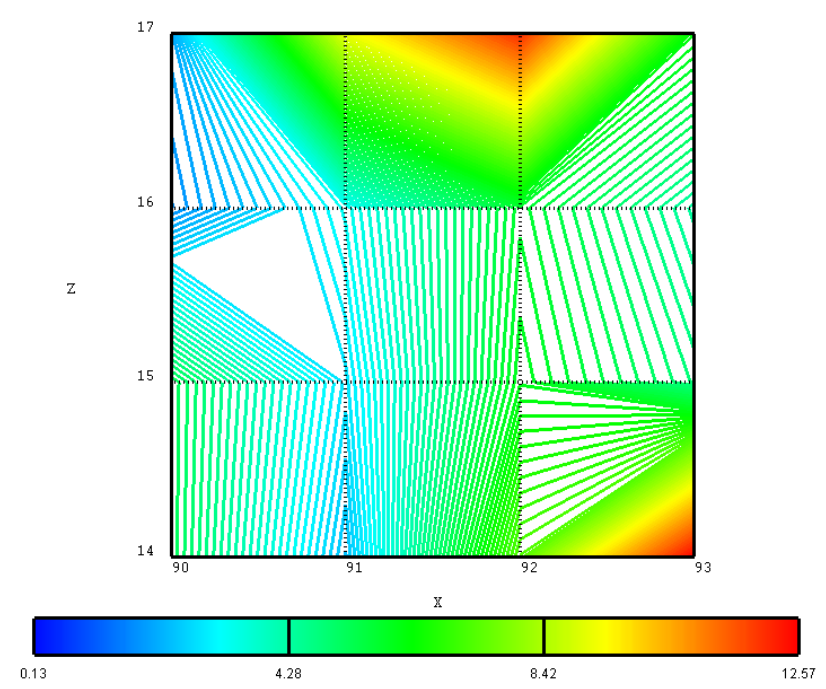

図-8 図-7と同じ ただし，電荷密度 $\left(1 \times 10^{-9}\left[\mathrm{C} / \mathrm{m}^{3}\right]\right)$ の鉛直 断面 (Y格子=143)

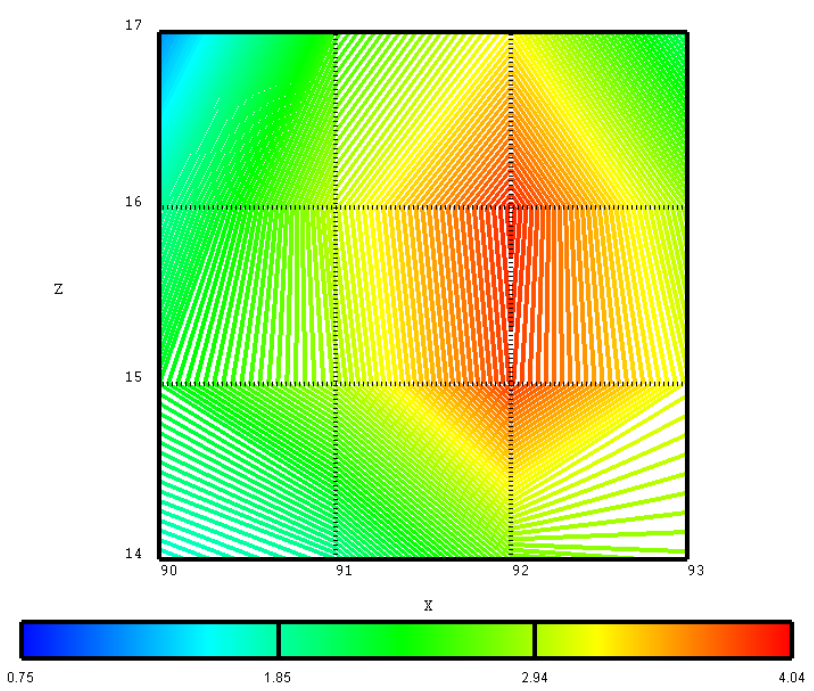

図-9 図-7と同じ ただし，電位 $\left(1.0 \times 10^{8}[\mathrm{~V}]\right)$ の鉛直断面 (Y格子=143) 


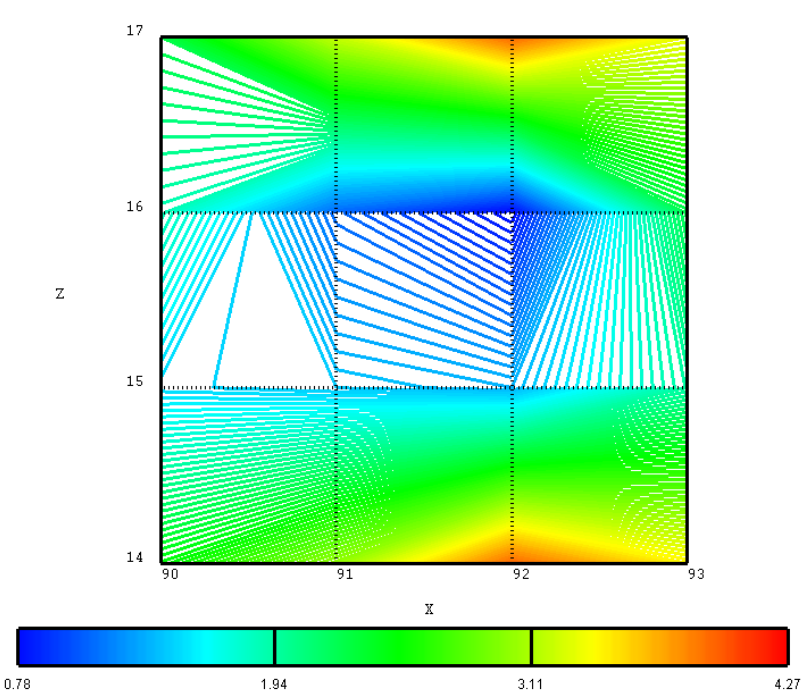

図-10 図-7と同じ ただし，電場 $\left(1.0 \times 10^{5}[\mathrm{~V} / \mathrm{m}]\right)$ の鉛直断 面 (Y格子=143)

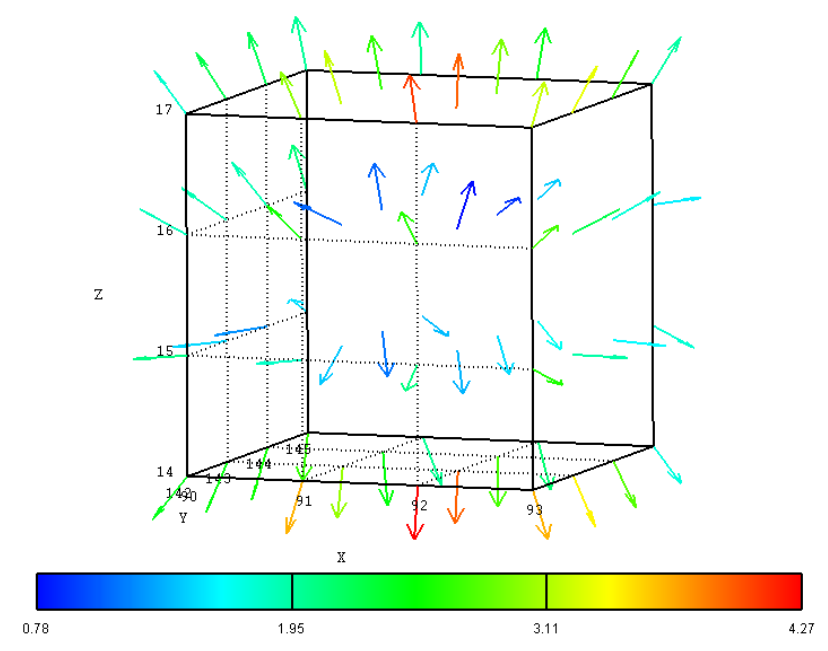

図-11 図-7と同じ ただし，電場ベクトル $\left(1.0 \times 10^{5}[\mathrm{~V} / \mathrm{m}]\right)$ の三次元分布図

図-6より，粒子判別の結果，すべての格子で霞が観測 されていることが分かる. また，霰と水晶の接触により 電荷分離が起こると述べた通り，ほとんどの格子で霰と 水晶の混在状態が観測された。

図-7から図-11より，霰の数濃度，電荷密度，電場はZ 格子 14 と 17 で大きく, 電位はZ格子 15 と 16 で大きいこと が分かる.

\section{(6) 考察}

図-7と図-8より，霞の数濃度が高い場所で電荷密度の 計算值が大きいことが分かる．このことから，霰と水晶 の接触により電荷が溜まっていることが考えられる。ま た，図-8と図-9より，電荷の差が大きいほど電位が大き くなっていることが分かる. $4 \times 4 \times 4$ 格子の外側境界条
件の電荷を0Cと置いたため，電荷が大きい方から小さ い方に電場が向き, 図-11のような電場ベクトルが形成 されたと考えられる.

\section{4. 結論と今後の課題}

本研究ではXバンドレーダーを用いて粒子判別された 降水粒子の粒径分布推定結果から大気中の電荷分布を算 出し, 電場の計算を行うアルゴリズムの構築を行った.

本研究の成果として，これまでは数值シミュレーショ ンでのみ可能であった電荷量と電場の算出について，X バンド偏波レーダーを用いて，リアルタイムで推定でき るようになった。 このことで，発雷，落雷のこれまでよ りも正確な予測を行う可能性をひらいたと言える.

本研究では $4 \times 4 \times 4$ という非常に狭い範囲での計算の ため, さらに広範囲での計算を行うこと, また，より時 間分解能が高い超小型Xバンド偏波レーダー（1分間で ボリュームスキャンを行う）を使用し，電荷量と電場を 算出することを今後の課題とする.

\section{参考文献}

1) 河崎善一郎 : 雷放電とは, Journal of Plasma Research Vol.80 No.7, pp.591, 2004.

2) Takahashi, T.: Riming electrification as a charge generation mechanism in thunderstorms. J. Atmos. Sci, Vol.35, pp.1536-1548, 1978.

3) MacGorman, D. R., Straka, J. M. and Ziegler, C. L.: A lightning parameterization for numerical cloud models. J. Apple. Meteor, Vol.40, 459-478, 2001.

4) 金子大志 : 雷モデルの開発，名古屋大学大学院修士論文, pp23-48, 2007.

5) 吉田智, $\mathrm{Wu}, \mathrm{T}$, 牛尾知雄, 高柳裕次 : 多地点 LF 帯センサ による雷放電リーダの三次元標定とレーダ反射因子との比較. 電気学会論文誌A, Vol.134 No.4, pp.188-196， 2014.

6) 中北英一, 隅田康彦，山口弘誠，鈴木賢士，中川勝広，川村 誠治 : 最新型偏波レーダーを用いた氷相降水粒子タイプの混 在状態推定に関する研究，京都大学防災研究所年報第53号 $\mathrm{B}$, pp.433-445, 2009.

7) Bringi, V. N. and Chandrasekar, V.: Polarimetric Doppler Weather Radar, Cambridge University Press, Cambridge, pp.63, 2001.

8) 深尾昌一郎, 浜津享助 : 気象と大気のレーダーリモートセン シング, 京都大学学術出版, pp.143-173, 2005.

9) 高橋劭: 雷の科学, 東京大学出版会, pp59-77, 2009.

10) ウェザーニューズ:ウェブページ http://weathernews.jp/

11) 気象庁:ウェプページ 過去の気象データ検索 http://www.data.jma.go.jp/obd/stats/etrn/index.php/

(2015. 9. 30受付) 